\title{
A STUDY ON SOCIO ECONOMIC STATUS AND ANTHROPOMETRIC CHARACTERISTICS AMONG DIFFERENT AGE LEVEL SCHOOL STUDENTS
}

\section{Rajkumar Maji*}

\section{Dr. Sudarsan} Biswas
Research Scholar, Department of Physical Education and Sport Science, Visva-Bharati University, Santiniketan, West Bengal, India. ${ }^{*}$ Corresponding Author

Associate Professor, Department of Physical Education and Sport Science, Visva-Bharati University, Santiniketan, West Bengal, India.

\section{ABSTRACT}

Background: Anthropometrical characteristics acquired by children and adolescents during growth and development are the impressive indicators of an individual's health and nutritional status as well as a mirror of the social and economic betterment of a country. Objective: The objective of the study is to compare the socio economic status and anthropometric characteristics among the different adolescent school students. Methods: Total four hundred and fifty $(n=450)$ adolescent male school students were considered as subjects from Paschim Medinipur, Hooghly and Howrah district of West Bengal. Socio economic status and anthropometrical characteristics were considered as variables. Socio economic status was measured by questionnaire and developed by Sunil Kumar Upadhyay \& Alka Saxena. Anthropometrical profile was measured by standard scientific measurements technique. Results: The present outcome reveals that anthropometric characteristics among school students increase in respect of their age. Conclusions: Findings associated that anthropometrical characteristics among the school students are significantly differed and increased according to chronological growth of age during the adolescent stage.

\section{KEYWORDS : Socio Economic Status; Adolescent; Anthropometry; School Students.}

\section{INTRODUCTION}

Growth is a physical aspect of development, which refers to the increase in size, shape, volume and weight of the body, caused by biological process [1]. It can be viewed as physical changes that occur from conception to maturity [2]. Physical growth comprises of all morphological modifications that characterize the span of a biological organism [3], modification known to take place during human ontogeny including changes in kind, number, size, shape, position [4], pigmentation and texture of body components $[5,6]$. Adolescence is the period of transition from childhood to adulthood [7]. W.H.O defines adolescence as the period of life between the ages of 10 to 19 years when the adolescent struggles to develop his individuality while still conforming to societal norms [8]. In the process of becoming a young adult, a person grows and matures in many ways [9]. Adolescence brings major changes in the body [10] making a man out of boy and a woman out of girl. Each organ of the body grows at different rates and reaches the climax of growth at different times [1]. Therefore, the growth of a population can be described as a mirror of ethnic conditions in society [11].

Social status is usually an important determiner of growth [12]. If the income effects are substantial and persistent and if the better-educated parents have superior consumption skill and are better informed of long-range health effects of consumption patterns they will usually be able to take better care of their off-spring. Body height and weight acquired by children and adolescents during growth and development [13] are the impressive indicators of an individual's health and nutritional status as well as a mirror of the social and economic betterment of a country [14].

Research is being carried on the impact of the environment on the development and on getting hereditarily and digit ratio [15] obtained exception. Studies reveal the domicile, socioeconomic status and standard of living as vital factors affecting biological development and health in several stages of life - [1621]. During the second half of the twentieth century in a study of Poland it was noticed that there is a link between children's height and socio economic status of the family $[22,23]$. The study also showed multiplying appearances of overweight and obesity among children in Poland. In Poland, prevalence of overweight extends up to $20 \%$ of primary school going children [24,25]. It is predicted that a family's socio economic status has an important role in overweight of the children - [2629].

\section{OBJECTIVES}

The objective of this study is to compare the socio economic status and anthropometric characteristics among the different adolescent school students.

\section{MATERIALS AND METHODS}

Participants

In this study total numbers of four hundred and fifty $(n=450)$ male students were selected as subjects from different Secondary standard schools of West Bengal. Paschim Medinipur, Hooghly and Howrah districts of West Bengal were delimited to investigate for this study. All the selected adolescent male students were voluntarily involved as subjects in this study. The subjects' age ranged from 12 to 14 years. Before randomization of the subjects the homogeneity test was acquired. Demographic data including resting heart rate, respiratory rate, blood pressure etc. were also taken from each participant.

\section{Variables Studied}

In this present research socio economic status and anthropometrical profile were considered as variables. Socioeconomic status was measured by standardized socioeconomic questionnaire and developed by Sunil Kumar Upadhyay \& Alka Saxena. Socio-economic status was categorized into following classification: high socio economic status, above average socio-economical status, average socio-economic status, below average socio-economic status, low socio-economic status. Socio-economic status scale is an accepted tool usually used by the sociologist for measuring socio economic status. The present scale is intended to measure the socio-economic status of both rural and urban areas. The scale consists of 31 items in five parts related to i) personal information, ii) family, iii) education, iv) income and v) others (cultural \& material possessions). The validity of the questionnaire is 0.78 and reliability is 0.83 . Anthropometrical profile was measured by standard scientific measurements 
technique. The standing height was measured by the stadiometer and body weight was measured by OMRON HN283-IN digital weight scale. The BMI was calculated by a formula $\left(\mathrm{kg} / \mathrm{mt}^{2}\right)$ i.e. by measuring standing height in meter and weight in kilograms.

Statistical Analysis

All the collected data was analyzed by descriptive statistics

viz. mean, standard deviation (SD), standard error of mean (SEM) to understand the general trends of the data. Further one-way analysis of variance (ANOVA) was employed for generalizing the significant differences among the different adolescent students in respect of their socioeconomic status and anthropometric growth pattern.

\section{RESULTS}

Table-1: Descriptive statistics of 12 years school students

\begin{tabular}{|c|c|c|c|c|c|c|c|c|}
\hline & \multirow[t]{2}{*}{$\mathrm{N}$} & \multirow[t]{2}{*}{ Mean } & \multirow[t]{2}{*}{ SD } & \multirow[t]{2}{*}{ SEM } & \multicolumn{2}{|c|}{ 95\% Confidence Interval for Mean } & \multirow[t]{2}{*}{ Minimum } & \multirow[t]{2}{*}{ Maximum } \\
\hline & & & & & Lower Bound & Upper Bound & & \\
\hline Socioeconomic status & 150 & 51.31 & 7.83 & 0.64 & 50.04 & 52.57 & 35 & 65 \\
\hline Height & 150 & 1.41 & 0.07 & 0.01 & 1.4 & 1.42 & 1.26 & 1.59 \\
\hline Weight & 150 & 33.03 & 7.86 & 0.64 & 31.76 & 34.3 & 21.5 & 65.1 \\
\hline Body mass index & 150 & 16.48 & 2.93 & 0.24 & 16.01 & 16.95 & 11.73 & 27.1 \\
\hline Femur bi-condylar diameter & 150 & 8.5 & 0.911 & 0.07 & 8.35 & 8.65 & 5.2 & 11 \\
\hline Humerus bi-condylar diameter & 150 & 5.38 & 0.72 & 0.059 & 5.26 & 5.5 & 3 & 9.7 \\
\hline Calf circumference & 150 & 27.27 & 3.08 & 0.25 & 26.77 & 27.77 & 19 & 38 \\
\hline Waist circumference & 150 & 63.54 & 8.1 & 0.66 & 62.23 & 64.84 & 51 & 89 \\
\hline Abdomen circumference & 150 & 62.29 & 8.98 & 0.73 & 60.85 & 63.74 & 48 & 97 \\
\hline Upper arm circumference & 150 & 19.91 & 2.63 & 0.22 & 19.48 & 20.33 & 15.5 & 28 \\
\hline Triceps skinfold & 150 & 9.77 & 5.18 & 0.42 & 8.93 & 10.6 & 3.4 & 28.2 \\
\hline Biceps skinfold & 150 & 5.9 & 3.9 & 0.32 & 5.27 & 6.52 & 2 & 20.6 \\
\hline Supra iliac skinfold & 150 & 8.78 & 6.68 & 0.55 & 7.7 & 9.86 & 2.4 & 30 \\
\hline Sub-scapular skinfold & 150 & 8.36 & 6.09 & 0.5 & 7.38 & 9.34 & 3 & 50 \\
\hline
\end{tabular}

Table-2: Descriptive statistics of 13 years school students

\begin{tabular}{|c|c|c|c|c|c|c|c|c|}
\hline & $\mathrm{N}$ & Mean & SD & SEM & 95\% Confider & Interval for Mean & Minimum & Maximum \\
\hline & & & & & Lower Bound & Upper Bound & & \\
\hline Socioeconomic status & 150 & 50.41 & 10.65 & 0.87 & 48.69 & 52.12 & 39 & 76 \\
\hline Height & 150 & 1.48 & 0.09 & 0.01 & 1.47 & 1.5 & 1.29 & 1.72 \\
\hline Weight & 150 & 38.04 & 9.67 & 0.79 & 36.47 & 39.59 & 22.2 & 67.6 \\
\hline Body mass index & 150 & 17.11 & 3.21 & 0.26 & 16.59 & 17.63 & 11.01 & 28.16 \\
\hline Femur bi-condylar diameter & 150 & 8.32 & 0.82 & 0.07 & 8.19 & 8.45 & 5.1 & 10.8 \\
\hline Humerus bi-condylar diameter & 150 & 5.6 & 0.55 & 0.04 & 5.52 & 5.69 & 4.5 & 7 \\
\hline Calf circumference & 150 & 29.07 & 3.75 & 0.31 & 28.46 & 29.67 & 23 & 40 \\
\hline Waist circumference & 150 & 67.22 & 8.21 & 0.67 & 65.9 & 68.55 & 54 & 91 \\
\hline Abdomen circumference & 150 & 65.47 & 9.96 & 0.81 & 63.86 & 67.08 & 49 & 97.5 \\
\hline Upper arm circumference & 150 & 20.72 & 2.9 & 0.24 & 20.25 & 21.19 & 15 & 30 \\
\hline Triceps skinfold & 150 & 9.22 & 5.03 & 0.41 & 8.41 & 10.03 & 3 & 30 \\
\hline Biceps skinfold & 150 & 5.58 & 3.54 & 0.29 & 5.01 & 6.15 & 2 & 21.6 \\
\hline Supra iliac skinfold & 150 & 9.45 & 7.35 & 0.6 & 8.26 & 10.64 & 2.4 & 36.6 \\
\hline
\end{tabular}

Table-3: Descriptive statistics of 14 years school students

\begin{tabular}{|c|c|c|c|c|c|c|c|c|}
\hline & \multirow[t]{2}{*}{$\mathrm{N}$} & \multirow[t]{2}{*}{ Mean } & \multirow[t]{2}{*}{$\mathrm{SD}$} & \multirow[t]{2}{*}{ SEM } & \multicolumn{2}{|c|}{ 95\% Confidence Interval for Mean } & \multirow[t]{2}{*}{ Minimum } & \multirow[t]{2}{*}{ Maximum } \\
\hline & & & & & Lower Bound & Upper Bound & & \\
\hline Socioeconomic status & 150 & 50.89 & 10.92 & 0.89 & 49.13 & 52.65 & 34 & 78 \\
\hline Height & 150 & 1.55 & 0.08 & 0.01 & 1.54 & 1.57 & 1.37 & 1.74 \\
\hline Weight & 150 & 43.1 & 11.7 & 0.95 & 41.21 & 44.98 & 6.7 & 97.1 \\
\hline Body mass index & 150 & 17.7 & 3.94 & 0.32 & 17.06 & 18.34 & 2.72 & 34.4 \\
\hline Femur bi-condylar diameter & 150 & 8.78 & 0.72 & 0.06 & 8.66 & 8.9 & 7.2 & 12 \\
\hline Humerus bi-condylar diameter & 150 & 5.9 & 0.6 & 0.05 & 5.8 & 6 & 4.4 & 8.1 \\
\hline Calf circumference & 150 & 30.21 & 4.21 & 0.34 & 29.53 & 30.88 & 3 & 46 \\
\hline Waist circumference & 150 & 69.95 & 8.47 & 0.69 & 68.59 & 71.32 & 55.5 & 103.5 \\
\hline Abdomen circumference & 150 & 68.03 & 10.22 & 0.83 & 66.38 & 69.68 & 51.5 & 110 \\
\hline Upper arm circumference & 150 & 22.29 & 3.26 & 0.27 & 21.77 & 22.82 & 16 & 33 \\
\hline Triceps skinfold & 150 & 9.66 & 5.65 & 0.46 & 8.75 & 10.58 & 3.4 & 35.4 \\
\hline Biceps skinfold & 150 & 5.48 & 3.63 & 0.3 & 4.89 & 6.06 & 2.4 & 22 \\
\hline Supra iliac skinfold & 150 & 10.15 & 7.13 & 0.58 & 9 & 11.3 & 3 & 43 \\
\hline Sub-scapular skinfold & 150 & 8.41 & 5.27 & 0.43 & 7.56 & 9.26 & 3.8 & 36.4 \\
\hline
\end{tabular}

Table-4: One way analysis of variance (ANOVA) among different adolescent school students

\begin{tabular}{|l|l|l|l|l|l|l|}
\hline Variables & & Sum of Squares & df & Mean Square & F & Sig. \\
\hline \multirow{2}{*}{ Socioeconomic status } & Between Groups & 60.84 & 2 & 30.42 & 0.311 & 0.733 \\
\cline { 2 - 8 } & Within Groups & 43783.16 & 447 & 97.95 & & \\
\hline \multirow{2}{*}{ Height } & Between Groups & 1.55 & 2 & 0.78 & 117.33 & 0.000 \\
\cline { 2 - 8 } & Within Groups & 2.95 & 447 & 0.01 & & \\
\hline \multirow{2}{*}{ Weight } & Between Groups & 7603.49 & 2 & 3801.74 & 39.03 & 0.000 \\
\cline { 2 - 8 } & Within Groups & 43538.43 & 447 & 97.4 & & \\
\hline \hline
\end{tabular}

46 GJRA - GLOBAL JOURNAL FOR RESEARCH ANALYSIS 


\begin{tabular}{|c|c|c|c|c|c|c|}
\hline \multirow[t]{2}{*}{ Body Mass Index } & Between Groups & 111.63 & 2 & 55.82 & 4.87 & 0.008 \\
\hline & Within Groups & 5123.96 & 447 & 11.46 & & \\
\hline \multirow[t]{2}{*}{ Femur bi-condylar diameter } & Between Groups & 16.08 & 2 & 8.04 & 11.98 & 0.000 \\
\hline & Within Groups & 300.06 & 447 & 0.67 & & \\
\hline \multirow[t]{2}{*}{ Humerus bi-condylar diameter } & Between Groups & 20.4 & 2 & 10.2 & 25.76 & 0.000 \\
\hline & Within Groups & 176.99 & 447 & 0.4 & & \\
\hline \multirow[t]{2}{*}{ Calf circumference } & Between Groups & 657.04 & 2 & 328.52 & 23.86 & 0.000 \\
\hline & Within Groups & 6155.74 & 447 & 13.78 & & \\
\hline \multirow[t]{2}{*}{ Waist circumference } & Between Groups & 3109.75 & 2 & 1554.87 & 22.79 & 0.000 \\
\hline & Within Groups & 30500.28 & 447 & 68.23 & & \\
\hline \multirow[t]{2}{*}{ Ābdomen circumference } & Between Groups & 2479.2 & 2 & 1239.6 & 13.08 & 0.000 \\
\hline & Within Groups & 42355.48 & 447 & 94.76 & & \\
\hline \multirow[t]{2}{*}{ Upper arm circumference } & Between Groups & 438.99 & 2 & 219.5 & 25.37 & 0.000 \\
\hline & Within Groups & 3859.32 & 446 & 8.65 & & \\
\hline \multirow[t]{2}{*}{ Triceps skinfold } & Between Groups & 25.45 & 2 & 12.72 & 0.45 & 0.635 \\
\hline & Within Groups & 12522.51 & 447 & 28.02 & & \\
\hline \multirow[t]{2}{*}{ Biceps skinfold } & Between Groups & 14.4 & 2 & 7.2 & 0.53 & 0.591 \\
\hline & Within Groups & 6106.29 & 447 & 13.66 & & \\
\hline \multirow[t]{2}{*}{ Supra iliac skinfold } & Between Groups & 139.97 & 2 & 69.98 & 1.41 & 0.247 \\
\hline & Within Groups & 22269.27 & 447 & 49.82 & & \\
\hline \multirow[t]{2}{*}{ Sub-scapular skinfold } & Between Groups & 0.82 & 2 & 0.41 & 0.01 & 0.987 \\
\hline & Within Groups & 14380.1 & 447 & 32.17 & & \\
\hline
\end{tabular}

${ }^{*}<0.05$ is considered to be significant.

Table-5: Schefee Post-hoc test for mean comparison among different adolescent school students.

\begin{tabular}{|c|c|c|c|c|c|}
\hline & Groups & & Mean Difference & Std. Error & Sig. \\
\hline \multirow[t]{3}{*}{ Height } & $12 y r s$ & $13 y r s$ & $0.07253^{*}$ & 0.0093 & 0.000 \\
\hline & $13 y r s$ & $14 y r s$ & $0.07120^{*}$ & 0.0093 & 0.000 \\
\hline & $14 y r s$ & 12yrs & $0.14373^{*}$ & 0.0093 & 0.000 \\
\hline \multirow[t]{3}{*}{ Weight } & $12 y r s$ & $13 y r s$ & $4.99800^{*}$ & 1.1396 & 0.000 \\
\hline & $13 y r s$ & $14 y r s$ & $5.07067^{*}$ & 1.1396 & 0.000 \\
\hline & $14 y r s$ & $12 y r s$ & $10.06867^{*}$ & 1.1396 & 0.000 \\
\hline \multirow[t]{3}{*}{ Body mass index } & 12yrs & 13yrs & 0.63209 & 0.3909 & 0.272 \\
\hline & $13 y r s$ & $14 y r s$ & 0.58765 & 0.3909 & 0.324 \\
\hline & $14 y r s$ & $12 y r s$ & $1.21974^{*}$ & 0.3909 & 0.008 \\
\hline \multirow[t]{3}{*}{ Femur bi-condylar diameter } & $12 y r s$ & 13 yrs & 0.17867 & 0.0946 & 0.169 \\
\hline & $13 y r s$ & $14 \mathrm{yrs}$ & $0.45933^{*}$ & 0.0946 & 0.000 \\
\hline & $14 y r s$ & $12 y r s$ & $0.28067^{*}$ & 0.0946 & 0.013 \\
\hline \multirow[t]{3}{*}{ Humerus bi-condylar diameter } & 12yrs & $13 y r s$ & $0.22387^{\star}$ & 0.0726 & 0.009 \\
\hline & $13 y r s$ & $14 y r s$ & $0.29600^{*}$ & 0.0726 & 0.000 \\
\hline & $14 y r s$ & 12yrs & $0.51987^{*}$ & 0.0726 & 0.000 \\
\hline \multirow[t]{3}{*}{ Calf circumference } & $12 y r s$ & $13 y r s$ & $1.79667^{*}$ & 0.4285 & 0.000 \\
\hline & $13 y r s$ & $14 y r s$ & $1.13867^{\star}$ & 0.4285 & 0.030 \\
\hline & $14 y \mathrm{rs}$ & $12 y r s$ & $2.93533^{*}$ & 0.4285 & 0.000 \\
\hline \multirow[t]{3}{*}{ Waist circumference } & $12 y r s$ & 13 yrs & $3.68733^{*}$ & 0.9538 & 0.001 \\
\hline & 13 yrs & 14yrs & $2.72800^{\star}$ & 0.9538 & 0.017 \\
\hline & $14 y r s$ & $12 y r s$ & $6.41533^{*}$ & 0.9538 & 0.000 \\
\hline \multirow[t]{3}{*}{ Äbdomen circumference } & 12yrs & $13 y r s$ & $3.17400^{*}$ & 1.1240 & 0.019 \\
\hline & 13yrs & 14yrs & 2.56467 & 1.1240 & 0.075 \\
\hline & $14 y r s$ & $12 y r s$ & $5.73867^{\star}$ & 1.1240 & 0.000 \\
\hline \multirow[t]{3}{*}{ Upper arm circumference } & $12 y r s$ & 13yrs & 0.81060 & 0.3402 & 0.060 \\
\hline & $13 y r s$ & 14yrs & $1.57167^{*}$ & 0.3396 & 0.000 \\
\hline & $14 y r s$ & $12 y r s$ & $2.38227^{\star}$ & 0.3402 & 0.000 \\
\hline
\end{tabular}

*The mean difference is significant at the 0.05 level.

\section{DISCUSSIONS}

The present study reveals that anthropometric characteristics among school students increase in respect of their age. This may be cause of the maturity in respect of age, their involvement in physical and sporting activities as it is a way to anticipate the happenings for which every child is eager to participate in physical and sporting activities if offered by a given facilities and proper equipments to participate whole heartedly in different sporting programmes [30,31]. The age is gradually acquired higher physical fitness -[32] and their physical demands are more [33]. In the age of 14 years the neuro physiological factor develops and continues still puberty "'"[34]. In this stage physical action increases more which may be due to the effects of structural growth $[35,36]$ on the myelination of neurons [37].

The previous study findings show that socio economic status helps to promote the BMI of an individual or a society, which may be a cause of proper nutritional supplements, parental education, family size, quality \& quantity of food, morbidity, physical activity, healthy habits, and level of stress $[24,38,39]$. Scientists reported that socio-economic variables are positively associated with anthropometric status and also mentioned that the children having poor anthropometric status perform more poorly on measures of child development as compared to peers with proper growth [40]. Scientists also 
noted that there is a significant relationship between height and higher levels of parental education. Research now tells us that height-weight ratio [41] has a direct positive relation with the family's size, education, income, resident, culture and life style of an individual or as a society. Higher level of per capita income is linked with higher weight and BMI. In addition to food consumption, physical activity may also act as a confounding factor in altering the body composition in adolescents [42]. Therefore, important social and cultural factors influencing the physical development of children and adolescents become a lifestyle, which is formed during socialization, as well as during later interactions of the individual, and is highly related to membership in a social class [24]. The above dissection corroborates the objectives of the present study.

\section{CONCLUSIONS}

Findings associated that anthropometrical characteristics among the school students are significantly differed and increased according to chronological growth of age during the adolescent stage.

\section{ACKNOWLEDGEMENTS}

The researchers are greatly acknowledged and thankful to all the school principals and students who were involved in the study.

\section{REFERENCES}

1. Kamlesh ML. Psychology in Physical Education and Sports. Metropolitan Book Co. Pvt. Ltd: 1998.

2. Singh A, Bains J, Gill JS, Brar RS. Essentials of Physical Education. Ludhiana: Kalyani Publishers; 2008

3. De A, Mondal S. Yoga and Brain Wave Coherence: A Systematic Review for Brain Function Improvement. Heart and Mind. 2020;4:33-9.

4. Loesch DZ, Stokes K, Huggins RM. Secular trend in body height and weight of Australian children and adolescents. Am J Phys Anthropol. 2000; 11 1:545-56.

5. Islam MS, Kundu B. Digit Ratio and Soccer. Orthopedics and Sports Medicine: Open Access Journal. 2019;3:227-30.

6. Schulz AH. Post-Embryomic Age Changes. Primatologia; 1956.

7. Friebel F, Hermanussen M. Scheffler C. Popular ideas and convictions about factors influencing the growth as well as the adult height of children: a German-French comparison. anthranz. 2019;76:365-70.

8. Roy T, De A. Beneficial Effect of Bratachari and Folk Games Programme on Blood Lipid Profile of Obese Adolescent. International Journal of Physical Education, Sports and Health. 2016;3:128-33.

9. Sweeting H, Hunt K. Adolescent socio-economic and school-based social status, health and well-being. Social Science \& Medicine. 2014;121:39-47.

10. Islam MS, Kundu B. Low Digit Ratio (2D: 4D) and Masculine Attributes: A Critical Analysis. International Journal of Research-GRANTHAALAYAH. 2020;8:384-90.

11. Tanner JM. Growth as a Measure of Nutritional and Hygienic Status of a Population. Horm Res. 1992;106-15.

12. Roy T, Roy D, De A. Modern Technology and Health Risk Factors: A Pedagogical Emergent for Social Wellbeing. International Journal of Current Trends in Science and Technology. 2017;7:20192-6.

13. De A, Mondal S. Improvement of Brain Function through Combined Yogic Intervention, Meditation and Pranayama: A Critical Analysis. European Journal of Physical Education and Sport. 2016;13:89-96.

14. Tanner JM. Growth as a Mirror of the Condition of Society: Secular Trends and Class Distinctions. Pediatr Int. 1987;29:96-103.

15. Islam MS, Kundu B. Soccer Passing Accuracy Differentiates Between High and Low Digit Ratio (2D: 4D) Soccer Players. American Journal of Sports Science. 2020;8:49-55.

16. Bruner MW, Lawson J, Pickett W, Boyce W, Janssen I. Rural Canadian adolescents are more likely to be obese compared with urban adolescents. International Journal of Pediatric Obesity. 2008:3:205-11.

17. Chen E, Martin AD, Matthews KA. Trajectories of Socioeconomic Status Across Children's Lifetime Predict Health. PEDIATRICS. 2007; 120:e297-303

18. Goodman E. The role of socioeconomic status gradients in explaining differences in US adolescents' health. Am J Public Health. 1999;89:1522-8.

19. Kobzová J, Vignerová J, Bláha P, Krejcovský L, Riedlová J. The 6th nationwide anthropological survey of children and adolescents in the Czech Republic in 2001. Cent Eur J Public Health. 2004;12:126-30.

20. Liu J, Bennett KJ, Harun N, Probst JC. Urban-Rural Differences in Overweight Status and Physical Inactivity Among US Children Aged 10-17 Years. The Journal of Rural Health. 2008;24:407-15.

21. Wang Y. Cross-national comparison of childhood obesity: the epidemic and the relationship between obesity and socioeconomic status. International Journal of Epidemiology. 2001;30:1129-36.

22. Bielecki EM, Haas JD, Hulanicka B. Secular changes in the height of Polish schoolboys from 1955 to 1988. Economics \& Human Biology. 2012;10:310-7.

23. Bielicki T, Szklarska A, Kozieł S, Welon Z. Political transformation in Poland in the light of anthropological research of 19-year-old males. Monografie Zakładu Antropologii Polskiej Akademii Nauk. 2003;
24. Gurzkowska B, Kułaga Z, Litwin M, Grajda A, wi der A, Kułaga K, et al. The relationship between selected socioeconomic factors and basic anthropometric parameters of school-aged children and adolescents in Poland. Eur J Pediatr. 2014;173:45-52

25. Kułaga Z, Litwin M, Tkaczyk M, Palczewska I, Zaj czkowska M, Zwoli ska D et al. Polish 2010 growth references for school-aged children and adolescents. EurJ Pediatr. 2011;170:599-609.

26. Andegiorgish AK, Wang J, Zhang X, Liu X, Zhu H. Prevalence of overweight, obesity, and associated risk factors among school children and adolescents in Tianjin, China. Eur J Pediatr. 2012;171:697-703.

27. Bielicki T, Szklarska A, Welon Z, Malina R. Variation in the body mass index among young adult Polish males between 1965 and 1995. Int J Obes. 2000;24:658-62.

28. Dong Y, Jan C, Ma Y, Dong B, Zou Z, Yang Y, et al. Economic development and the nutritional status of Chinese school-aged children and adolescents from 1995 to 2014: an analysis of five successive national surveys. The Lancet Diabetes \& Endocrinology. 2019;7:288-99.

29. Zsakai A, Bodzsar EB. The relationship between body structure and the socioeconomic status in Hungarian children and adolescents. Coll Antropol. 2014;38:479-85.

30. De A, Ghosh SN. Effect of Healthy Activity Programmes on Kinesthetic Perception and Self-Concept among School Students. International Journal of Advanced Scientific Research. 2016;1:29-33.

31. Roy D, De A. Effect of Aging on Psycho-Motor Components in Relation to Perceived Stress among Healthy Citizens. International Journal of Movement Education and Social Science. 2018;7:1-6.

32. Islam MS. Relationship of Abdominal Muscle Endurance with Selected Anthropometric Measurements in Soccer Players. Int J Physiol Nutr Phys Educ. 2018;3:1088-90.

33. Baum CL, Ruhm CJ. Age, socioeconomic status and obesity growth. Journal of Health Economics. 2009;28:635-48.

34. De A, Jana A, Bag S. A Study on Coordinative Ability and Kinesthetics Perception in Relation to Emotional and Behavioural Problems among Santal Students. International Journal of Humanities and Social Science Research. 2016:2:65-9

35. Roy T, De A, Nandi SC. A Study on Mental Toughness in Relation to Agility and Reaction Ability among Female Kho Kho Players. International Journal of Home Science. 2016;2:406-9.

36. Saleh SM, El Sherif MA. Growth and nutritional status of rural preschool children in El Minia governorate. New Egypt J Med. 1993:8:820-3.

37. De A, Mondal S. Immediate Effect of Yogic Postures on Autonomic Neural Responses. Research in Cardiovascular Medicine. 2019;8:106-13.

38. Ghosh SN, De A, Mondal S. Stress Hormones and Sports Performance: A Critical Analysis. International Journal of Physiology, Nutrition and Physical Education. 2018:3:1752-7.

39. Maji R, Biswas S. A Relationship Study between Socio Economic Status and Growth Status of School Students. International Journal of Physiology, Nutrition and Physical Education. 2020;5:146-50.

40. Abubakar A, van de Vijver F. Socioeconomic Status, Anthropometric Status and Developmental Outcomes of East-African Children. In: Preedy VR, editor Handbook of Anthropometry: Physical Measures of Human Form in Health and Disease [Internet]. New York, NY: Springer; 2012 [cited 2020 May 15]. p. 2679-93. Available from: https://doi.org/10.1007/978-1-4419-1788-1_167

41. Islam MS, De A. Functional Hamstring to Quadriceps Strength Ratio (H:Q) and Hamstrings Injury of Soccer Players: A Qualitative Analysis. Orthopedics and Sports Medicine: Open Access Journal. 2018;2:126-32.

42. Thakur A. Influence of Socioeconomic Status on Anthropometric Measurements in Secondary School Children in Mumbai, India. International Journal of Science and Research. 2016;5:682-5. 